Rochester Institute of Technology

RIT Scholar Works

Articles

Faculty \& Staff Scholarship

Winter 12-12-2018

\title{
Stimulating interethnic contact in Kosovo: The role of social identity complexity and distinctiveness threat
}

\author{
Edona Maloku \\ Leiden University; RIT Kosovo \\ Belle Derks \\ Utrecht University \\ Colette Van Laar \\ Leuven University College \\ Naomi Ellemers \\ Utrecht University
}

Follow this and additional works at: https://scholarworks.rit.edu/article

Part of the Social and Behavioral Sciences Commons

\section{Recommended Citation \\ Maloku, E., Derks, B., van Laar, C., \& Ellemers, N. (2019). Stimulating interethnic contact in Kosovo: The role of social identity complexity and distinctiveness threat. Group Processes \& Intergroup Relations, 22(7), 1039-1058. https://doi.org/10.1177/1368430218808884}

This Article is brought to you for free and open access by the Faculty \& Staff Scholarship at RIT Scholar Works. It has been accepted for inclusion in Articles by an authorized administrator of RIT Scholar Works. For more information, please contact ritscholarworks@rit.edu. 


\section{Stimulating interethnic contact in Kosovo: The role of social identity complexity and distinctiveness threat}

Group Processes \& Intergroup Relations

Article reuse guidelines: sagepub.com/journals-permissions DOI: $10.1177 / 1368430218808884$ journals.sagepub.com/home/gpi

(S)AGE

\author{
Edona Maloku, ${ }^{1}$ Belle Derks, ${ }^{2}$ Colette van Laar $^{3}$ (iD \\ and Naomi Ellemers ${ }^{2}$
}

\begin{abstract}
The positive effects of intergroup contact on prejudice reduction have been widely validated by now. However, the potential of contact for intergroup relations is only available when there is readiness to have contact with outgroup members to begin with. In two correlational studies with the main ethnic groups in postconflict Kosovo, Albanian majority (Study 1, $N=221$ ) and Serb minority (Study 2, $N=110$ ), we examine how social identity complexity mechanism and distinctiveness threat contribute to predicting more readiness to have contact with outgroup members. As the establishment of a new national identity unfolds, we show that while there are different processes that work for each of the groups, distinctiveness threat is a central concern to both as it mediates the relationship between identity and intergroup outcomes. For the Albanian majority group, having more complex identities (or perceiving less identity overlap between national and ethnic identity) predicts more readiness to have contact and feeling more positively towards members of the outgroup via reduced distinctiveness threat. For the Serb minority, however, threat is predicted only by strength of ethnic identification, which in turn predicts negative feelings towards members of the ethnic outgroup and less readiness to contact them. We conclude by comparing results for the majority and the minority groups and discuss strategies needed to reduce threat and improve intergroup relations in this segregated context struggling for reconciliation.
\end{abstract}

\title{
Keywords
}

distinctiveness threat, postconflict relations, readiness to have contact, social identity complexity, superordinate categorization

Paper received 1 November 2017; revised version accepted 28 September 2018.

\footnotetext{
${ }^{1}$ Leiden University, the Netherlands

${ }^{2}$ Utrecht University, the Netherlands

${ }^{3}$ University of Leuven, Belgium
}

\author{
Corresponding author: \\ Edona Maloku, Institute for Psychological Research, Social \\ and Organizational Psychology Unit, Leiden University, P.O. \\ Box 9555, 2300 RB Leiden, the Netherlands. \\ Email: emaloku@auk.org
}




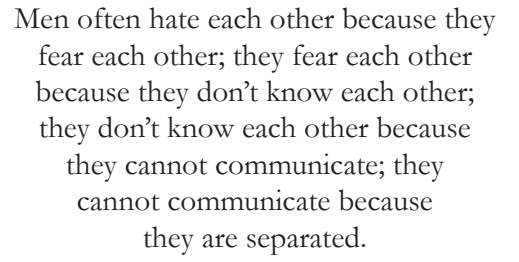

Martin Luther King Jr., 1962

In postconflict contexts people are challenged with having to leave the past behind and reshaping the future. However, this is often hard to do because intergroup segregation and negative intergroup attitudes tend to linger long after the conflict has ended (Wohl \& Branscombe, 2005). Kosovo, the postconflict context that is the focus of the current investigation, is still faced with reconciliation barriers since the conflict ended in 1999 with an international military intervention. Kosovo had been part of the former Yugoslavia and remained a formal part of Serbia after the Yugoslav federation collapsed. Kosovo's two main ethnic groups, the overwhelming Albanian majority (87\% of the population) and the Serb minority (an estimated 8\%), ${ }^{1}$ have a long history of differences that have further intensified with Kosovo's declaration of independence from Serbia in 2008. While for ethnic Albanians this act was viewed as historically just, for ethnic Serbs it represented fragmenting the heart of the Serbian identity (Judah, 2008). Now, these two groups have the daunting task of overcoming their past and learning how to live together in the newborn state. ${ }^{2}$ For Kosovar nationals, one of the biggest challenges remains how to negotiate their new national identity with their ethnic identity. In this paper, we shed light onto this process by examining how different processes related to social identity, namely social identity complexity, ethnic identification, and distinctiveness threat, predict Kosovar Albanians' and Serbs' overall feelings towards their ethnic outgroup and their readiness to have contact with them.

\section{Intergroup Relations in Kosovo}

An important characteristic of intergroup relations in Kosovo is that the two groups under investigation live highly segregated from each other. Since the end of the conflict in 1999, the minority group of Kosovar Serbs has for the most part resettled in pocket areas around the country. This limits opportunities for contact with Kosovar Albanians as an effective way to improve intergroup relations (Allport, 1954; Blair, Park, \& Bachelor, 2003; Islam \& Hewstone, 1993; Pettigrew, 1998; Pettigrew \& Tropp, 2006). Apart from reducing stereotypes and prejudice, contact has been shown to predict positive emotions and behaviors towards outgroups (D. A. Miller, Smith, \& Mackie, 2004). However, most of this research has been conducted in contexts where there already is contact (Esses \& Dovidio, 2002). The present research adds to this literature by examining social identity processes that predict people's readiness to have contact with outgroup members in a context where intergroup contact is scarce.

In the current studies, we examine two separate aspects of social identity, namely the quality of a new superordinate categorization (e.g., common ingroup identity model [CIIM]; Gaertner \& Dovidio, 2000) and identity complexity (social identity complexity [SIC]; Roccas \& Brewer, 2002). This is important because these two aspects of identity and the threat versus opportunities they represent have not been studied concurrently so far. In addition, we examine these mechanisms by simultaneously comparing majority and minority groups and how they respond to these identity processes while the national identity is still being developed.

\section{Superordinate Categorization Among Ethnic Albanians and Ethnic Serbs: Will It Work?}

Previous work on superordinate categorization suggests that the creation of the new superordinate identity of the Kosovar national in 2008 
could provide an opportunity for the improvement of interethnic relations between Albanians and Serbs in Kosovo. This type of regrouping offers an overarching vessel through which former outgroup members can now be conceived as ingroup members, resulting in positive effects of ingroup bias being "transferred" to former outgroup members (Gaertner, Dovidio, Anastasio, Bachman, \& Rust, 1993). For example, research on the common ingroup identity model (Gaertner \& Dovidio, 2000) has shown that when a superordinate category is made salient (in this case, Kosovar national identity), members of different subordinate groups (i.e., Albanian and Serb ethnic groups) can start conceiving themselves as part of the common superordinate category. In other words, the previous "us" and "them" categorizations based on subgroups come to be perceived as "we" at the superordinate level. Superordinate categorization has been found to improve intergroup relations through its beneficial effects on outgroup attitudes (Brewer, 1979; Dovidio, Gaertner, \& Saguy, 2009; Gaertner \& Dovidio, 2000) and its reduction of intergroup threat (Riek, Mania, Gaertner, McDonald, \& Lamoreaux, 2010).

However, research has also shown that recategorization does not necessarily come as naturally to minority group members as it does for the majority. Endorsing a superordinate identity might be easy for members of majority groups because the overarching identity is perceived to implicitly represent their group's dominant values as the default (Devos \& Banaji, 2005) and majority groups are more likely to see themselves as prototypical of the superordinate category, leading them to more strongly project features of their group onto the superordinate identity (ingroup projection model [IPM]; Mummendey \& Wenzel, 1999). In support of this reasoning, research has found a positive correlation between ethnic (subordinate) and national (superordinate) identities among ethnic majority groups, but no correlation or even a negative one for ethnic minorities (e.g., Israeli Jews or Euro-Americans in the United States: Sidanius, Feshbach, Levin, \& Pratto, 1997; Sinclair, Sidanius, \& Levin, 1998; or minority
Turkish Dutch in the Netherlands: Verkuyten \& Martinovic, 2012, Study 2). If Albanians perceive the Kosovar identity to be highly similar to their Albanian ethnic identity, then they are likely to perceive the Serb minority as not fitting this category. Given that higher ingroup projection relates to more negative attitudes towards outgroups (Waldzus \& Mummendey, 2004), it could well be that for Albanians, identification with the Kosovar identity does not predict more positive evaluation of Serbs, so the overarching function of this identity is hindered.

Unlike the majority, members of minority groups often react more negatively towards recategorization, as they seek to preserve the values of their distinctive subordinate groups, especially when status differences with the majority are perceived to be illegitimate and impermeable (Bettencourt, Dorr, Charlton, \& Hume, 2001; Mullen, Brown, \& Smith, 1992), which is likely the case for Kosovar Serbs given that Albanians and Serbs have continuously struggled to dominate each other (Daskalovski, 2003). Literature on corporate mergers offers a good analogy for how minority ethnic groups could respond to national identity formation and why they might resist it. For example, research on real-life mergers suggests that mergers induce negative reactions because people feel they have to abandon a valued group identity (Terry, Carey, \& Callan, 2001). In corporate mergers, members of the dominant group (majority) respond differently to members of the nondominant group (minority). Experimental work revealed that while members of the dominant group previous to a merger perceive the merged identity as a continuation of "their" previous identity, members of the nondominant group perceive that they have to adopt a new identity (van Leeuwen, van Knippenberg, \& Ellemers, 2003). Thus, minority group members (Serbs in our case) are then more likely to resist identifying with the national identity due to perceived ethnic identity loss. In the current studies, we aimed to examine whether previous findings on social identity and the common ingroup identity model would replicate in a delicate and understudied context such as Kosovo. Therefore, 
our first hypothesis was that Albanians (the majority) will identify more strongly with the Kosovar national identity than Serbs (the minority; H1).

\section{Relevance of Ethnic Identity}

Vast research within the social identity tradition (social identity theory: Tajfel \& Turner, 1979, 1986; self-categorization theory: Turner, 1985; Turner, Hogg, Oakes, Reicher, \& Wetherell, 1987) shows that people relate to one another as members of the social categories or groups they perceive to belong to by categorizing the social environment into "us" and "them" (Dovidio, Gaertner, \& Saguy, 2007). People systematically evaluate their ingroups more favourably than outgroups as a way to maintain a positive distinct social identity (Brown, 2000; Turner, 1999), and this often forms the psychological basis for prejudice, stereotyping, discrimination, or even group conflict (Brown, 1995; Dovidio et al., 2007; Tajfel \& Turner, 1979). However, which social categories become meaningful and are perpetuated is contingent upon contextual factors like immediate social environments as well as the particular political, historic, and economic circumstances (Ashmore, Deaux, \& McLaughlin-Volpe, 2004; Ellemers, Spears, \& Doosje, 2002). Given that ethnicity has been historically at the heart of tensions between Albanians and Serbs in Kosovo (Daskalovski, 2003) and that groups that experience prejudice and discrimination can show higher ethnic identification (e.g., in South Africa; Twenge \& Crocker, 2002), we predicted that both ethnic groups would show high ethnic identification. Although there are benefits to high ethnic identification because it can help to reduce uncertainty in the social world (Hogg, 2000), to cope against perceived discrimination (especially for minority groups; Cronin, Levin, Branscombe, van Laar, \& Tropp, 2012), and to cope with identity threats (Verkuyten \& Yildiz, 2007), high group identification can also predict less favourable attitudes towards outgroups (Brown, 2000). As in Hypothesis 1, we aimed to replicate previous findings among the specific understudied groups under consideration, and tested whether ethnic identification would indeed be high among both Kosovar Albanians and Kosovar Serbs and associated with less favourable responses toward the outgroup-less readiness to contact members of the outgroup and more negative feelings towards them (H2).

\section{Integrating Nationality and Ethnicity Through Social Identity Complexity}

As described, we predict that superordinate identification with the Kosovar national identity will not yet help to improve intergroup relations. Instead, we argue that in the context of introducing a new overarching identity, social identity complexity (SIC) could be an important variable in predicting and improving intergroup relations (Roccas \& Brewer, 2002). The SIC perspective posits that simply belonging to multiple social categories that are cross-cutting (e.g., Albanians and Serbs as Kosovar nationals) in itself is not sufficient for positive intergroup attitudes to emerge. Instead, it is crucial to understand how much overlap and similarity people perceive between the multiple ingroups that define their social identity (e.g., nationality, ethnicity, religion). Roccas and Brewer (2002) posit that SIC can range on a continuum from low to high and includes two distinct but related subcomponents: overlap complexity (representing group composition) and similarity complexity (representing similarity between group prototypes). To illustrate, the left panel of Figure 1 represents a Kosovar Albanian Muslim with low identity complexity. This person perceives these three categories as highly overlapping (so that she perceives Kosovars as being Albanian and Muslim, but would not include Kosovars with other ethnicities or religions as part of her ingroup) or perceives these groups as highly similar (so that, to her, the prototypical Albanian is very similar to the prototypical Kosovar and Muslim). In contrast, the same person would have high identity complexity (see Figure 1, right panel) when she perceives less overlap and less similarity between these three categories and, 


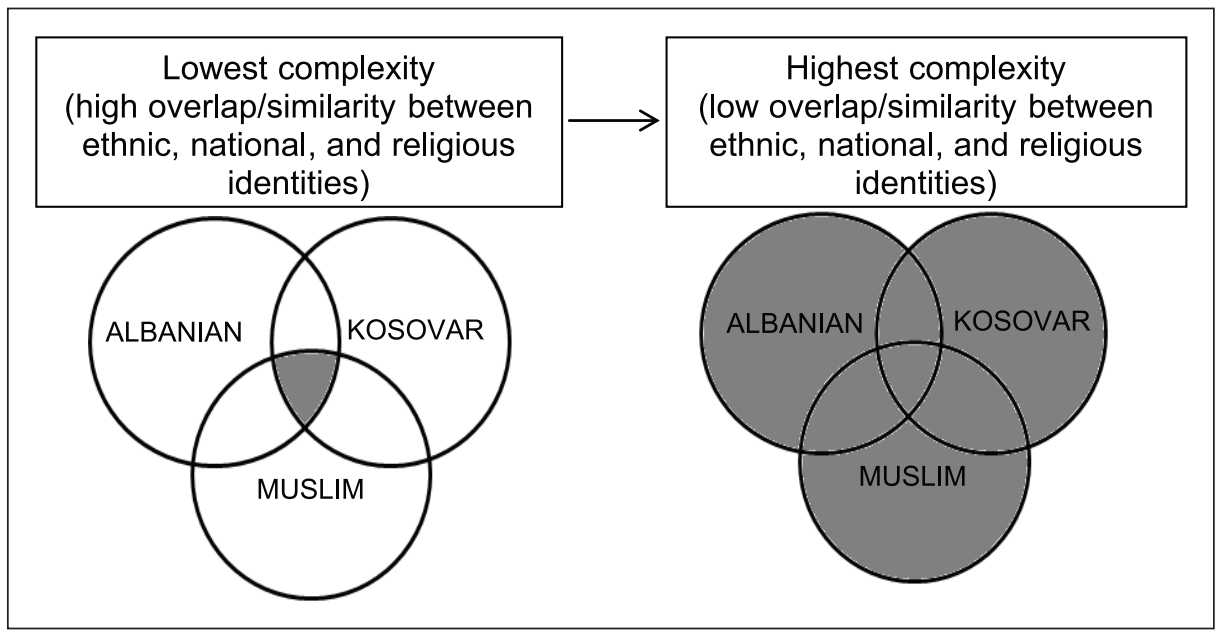

Figure 1. Social identity complexity (Roccas \& Brewer, 2002) explained as the perceived ingroup overlap or similarity of ethnic, national, and religious identities for the Albanian majority in Kosovo.

Note. Grey area indicates individuals who are perceived as ingroup members.

as a result, considers everyone who shares one of these identities (so also Kosovar Serbs, or Albanians with different nationalities) as fellow ingroup members.

Past research shows that a more complex identity is associated with a range of beneficial intergroup outcomes, including being more open towards others and evaluating them positively (Brewer \& Pierce, 2005; K. P. Miller, Brewer, \& Arbuckle, 2009), trusting others more (Xin, Xin, \& Lin, 2016), and perceiving less threat to the distinctiveness of their group (Schmid, Hewstone, Tausch, Cairns, \& Hughes, 2009). It has been found that higher SIC more easily develops when people are exposed to contact experiences, diversity, and to a multicultural society (Brewer, 2010; Schmid, Hewstone, \& Al Ramiah, 2013; Schmid et al., 2009). Consistent with this, we reasoned that Kosovo's segregated setting provides little opportunity for people to develop high SIC to begin with. Also, the predicted differences in national identification between Albanians and Serbs (see H1) would likely be reflected in their SIC. More specifically, we expected that the majority group of Kosovar Albanians would show lower SIC, as they would perceive high overlap and similarity between
Albanian and Kosovar identities. Kosovar Serbs, on the other hand, would report more SIC as they would perceive less overlap and similarity between Serb and Kosovar identities (H3). Our predictions are in opposition to what Brewer, Gonsalkorale, and van Dommelen (2013) found in Australia where majority members (AngloEuropeans) reported more SIC compared to minority members (Asian Australians). However, this finding could be related to the specific context and groups examined. Australia's pluralistic society offers ethnic groups more opportunities for intergroup experiences whereby people are able to develop more inclusive ingroup compositions. Such reality may be very different from Kosovo's segregated society. Moreover, the minority group (Asian Australians) sampled in Brewer et al.'s (2013) studies is a numerically well-established group in the country and is often overrepresented in university contexts, where studies were conducted. Given that the numerical difference between Albanian majority and Serb minority in Kosovo is large (only 8\% of Kosovars are Serbs) and that we hypothesized national identification differences between these groups, it is logical to expect the predicted mean differences in our samples. 


\section{Does Distinctiveness Threat Frustrate Positive Intergroup Relations?}

The current identity-building process requires that Kosovar Albanians and Kosovar Serbs reevaluate old identities and negotiate what the new identity means to them. Because of this, both ethnic groups are likely to experience an identity-based threat and be particularly concerned with their group's distinctiveness - a need to perceive their own ethnic group as unique and positively distinct from other ethnic groups (Jetten, Spears, \& Manstead, 2001; Jetten, Spears, \& Postmes, 2004; Riek, Mania, \& Gaertner, 2006). Previous research has shown that people who are strongly identified with their subgroup identities, as we predicted to be the case with these ethnic groups (see H2), are more likely to experience threat than those for whom ethnic identity is less central to their identity (Bizman \& Yinon, 2001). Moreover, perceptions of threat motivate groups to defend their threatened identity, leading to attempts to differentiate from the relevant outgroups (Jetten, Spears, \& Manstead, 1997; Tajfel \& Turner, 1986). Threat prompts more intergroup competition, is associated with more prejudice and bias towards outgroups and with an intensification of (sub)group identification (Branscombe, Ellemers, Spears, \& Doosje, 1999; Tausch, Hewstone, Kenworthy, Cairns, \& Christ, 2007). We reasoned that distinctiveness threat could result in negative intergroup relations and thus, would further sustain the problematic intergroup relations.

\section{The Present Research}

In two studies we examine the role of identity complexity among Albanians (Study 1) and Serbs (Study 2) in Kosovo in predicting intergroup outcomes, namely readiness to have contact with outgroup members and feelings towards them. The inclusion of outgroup members as part of the ingroup is more easily achieved when people have a complex rather than a simple identity. We therefore predict that a more complex identity will predict positive intergroup outcomes. Although previous research has examined the relationship of contact and complexity in contexts with intergroup divisions and majority-minority contexts (e.g., Israel: Roccas \& Brewer, 2002; Northern Ireland: Schmid et al., 2009), few studies have investigated how complexity predicts readiness to have contact with the outgroup within a setting where contact is almost absent. In addition, there is still limited research that focuses on the implications of SIC for majority as well as minority groups at the same time (Brewer et al., 2013). We aim to extend this literature by examining how the complexity mechanism contributes to predicting intergroup outcomes, while simultaneously comparing majority-minority groups that come from a postconflict context that is as segregated and as understudied as Kosovo is.

Our alternative approach therefore is to look at SIC as a way to reduce threat and improve intergroup outcomes. We predict that, for people with a more complex identity, the distinctiveness of their ethnic group is less of a concern, which subsequently predicts more positive feelings towards the outgroup and more readiness to have contact with them. At first sight, our prediction may seem in contrast to previous correlational work (see Schmid et al., 2009), which found SIC to be predicted by both level of contact and distinctiveness threat. However, Schmid et al.'s (2009) study was conducted in a context where there already was intergroup contact, whereas our studies examine how complexity relates to the readiness of people to engage in outgroup contact and how they feel towards this outgroup in contexts where contact is highly limited or even absent.

We proposed a theoretical model (see Figure 2) where higher SIC predicts more positive intergroup outcomes because it results in less distinctiveness threat. Additionally, we predicted distinctiveness threat to mediate the negative effect of high ethnic identification on intergroup outcomes (H4). ${ }^{3}$ We test this model in the two ethnic groups to see whether the processes are similar for both.

It is important to point out that the context in which these studies were conducted represents an 


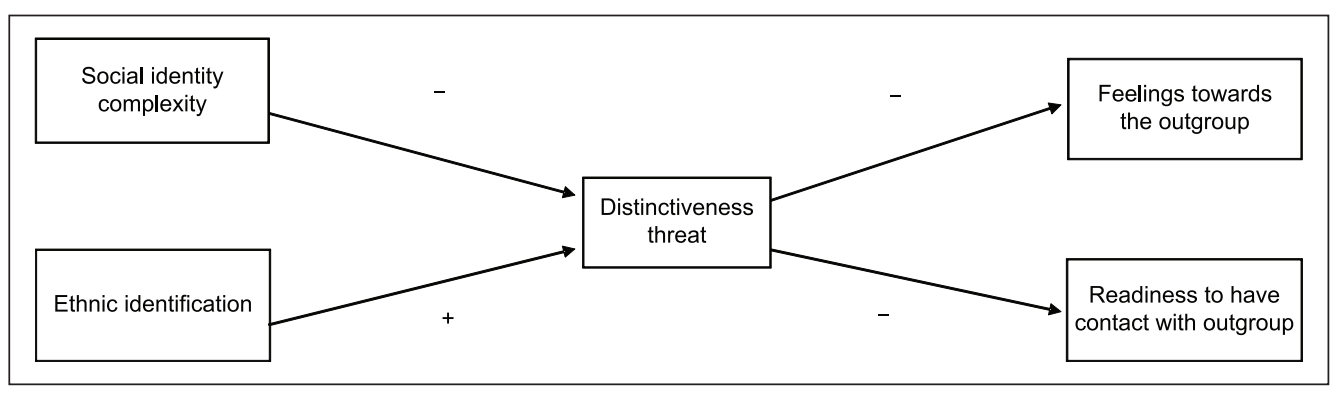

Figure 2. Theoretical model hypothesizing relationships between constructs.

unprecedented opportunity to study identity processes as a new identity develops. It offers us a chance to understand whether complexity can help in the peace-building process as it happens. To the best of our knowledge, these studies are contextually novel as well (see Maloku, Derks, van Laar, \& Ellemers, 2016, for an overview of identity in Kosovo). The only previous study that we are aware of (Andrighetto, Mari, Volpato, \& Behluli, 2012), examined effects of superordinate identification and extended contact, and showed that they both negatively predict competitive victimhood of Albanians towards Serbs in Kosovo. ${ }^{4}$ However, this study included only an Albanian sample and did not measure identification with the new Kosovar identity explicitly, like we do.

\section{Studies 1 and 2}

\section{Method}

Participants and design. We performed two online survey studies among Kosovo Albanian students (Study 1, conducted in June 2014 in respondents' native Albanian language) and Kosovo Serb students (Study 2, conducted in February 2015 in respondents' native Serb language). Although the studies were the same in content, we treat them as two separate studies because they were conducted at different points in time. The studies were part of larger surveys and were approved by the Ethics Committee of Leiden University. Study 1 consisted of 221 participants of Albanian ethnicity (178 women; $M_{\text {age }}=22.30, S D=3.87$ ). Most participants came from urban rather than rural settings (68\%). Participants in Study 2 were 110 students of Serb ethnicity ( 73 women; $M_{\text {age }}=$ $23.64, S D=3.66)$ in one of the segregated areas of the country, the north of the country that is adjacent to Serbia. The Serbian sample was also mixed; $45 \%$ of participants came from urban rather than rural areas. We recruited University of Prishtina and University in North Mitrovica students through student mailing groups from two locations: the country capital Prishtina where majority are Albanians (Study 1), and North Mitrovica, located in this northern city where Serbs live in a segregated area (Study 2). All participants were students of either Albanian or Serbian ethnicity with Kosovar citizenship. Participation was anonymous and voluntary. After the study ended, 10 prizes of $€ 15.00$ per study were awarded through a draw.

Procedure and measures. After providing informed consent, participants were asked to complete a number of measures, as listed in what follows. ${ }^{5}$

Social identity complexity. To make group identification salient, participants were initially shown a list of six broad group memberships (Group Elicitation Questionnaire; adapted from K. P. Miller et al., 2009) across different domains: ethnicity, nationality (as mentioned in passport), ${ }^{6}$ student group (either university or high school), religion, family socioeconomic background, and regional background. Next, participants were shown the group memberships they listed (except for ethnic and national identity) and asked to indicate their two most important groups. Then, 
participants were presented with the measures of identity overlap and similarity, which were based on four groups: nationality, ethnicity, and the two most important groups as selected by participants from the remaining list of categories (for over $80 \%$ of participants, these were student and religious identity).

First, we measured identity overlap. Participants were given two practice items. Then, they responded to a total of 12 pairs of overlap (or 24 items) measures in each direction of group comparison; for example, "When you think about people who are Kosovar, how many of them are Albanian?"; "When you think about people who are Albanian, how many of them are Kosovar?" $(1=$ none of them are, $11=$ all of them are $)$. The index of overlap was created by calculating the aggregated mean of all pairs $\left(\alpha_{\text {Albanians }}=.81\right.$, $\left.\alpha_{\text {Serbs }}=.92\right)$.

Second, similarity complexity was measured. Participants responded to six questions that measured prototypicality of the four focal identities; for example, "In general, the typical Kosovar is very similar to the typical Albanian" ( $1=$ strongly disagree, $7=$ strongly agree $)$. The index of similarity was reliable in both studies $\left(\alpha_{\text {Albanians }}=.85\right.$, $\alpha_{\text {Serbs }}=.84$ ). Both indices of SIC were recoded for analysis so that higher numbers indicate higher SIC (i.e., less overlap and less similarity).

Strength of social identification. Identification with nationality (Kosovar) and ethnicity (Albanian or Serb) was measured by adapting items from Leach et al.'s (2008) multicomponent model of ingroup identification. We measured three solidarity items ("I feel a bond with Kosovars," "I feel committed to Kosovars," and "I feel solidarity with Kosovars"; $1=$ not at all, $7=$ very much), two satisfaction items ("I think that Kosovars have a lot to be proud of" and "It is pleasant to be Kosovar"), and two centrality items ("I often think about the fact that I am Kosovar" and "Being Kosovar is an important part of how I see myself"). Items formed reliable scales (ethnicity: $\alpha_{\text {Albanians }}=.92, \alpha_{\text {Serbs }}=.92$; nationality: $\alpha_{\text {Albanians }}=.92, \alpha_{\text {Serbs }}=.95$ ).

Distinctiveness threat. We measured distinctiveness threat with two items: "I think it is important to emphasize the differences between Albanians and Serbs" (adapted from Jetten et al., 1997) and "It annoys me when others don't notice the differences between Albanians and Serbs" (adapted from Schmid et al., 2009; $r_{\text {Albanians }}=.72$, $p<.001 ; r_{\text {Serbs }}=.68, p<.001 ; 1=$ strongly disagree, $7=$ strongly agree $)$.

Intergroup outcomes. Quantity of outgroup contact was measured with one item ("Overall, how much contact do you personally have with Kosovo Serbs [Albanians]?"; $1=$ never, $7=$ on a daily basis). Readiness to have outgroup contact was measured with eight items (adapted from Roccas \& Brewer, 2002 and United Nations Development Programme [UNDP], 2012) asking participants to what extent they would find it personally acceptable to engage in a number of social interactions with an outgroup member, namely (a) Live in the same street as a Kosovo Serb [Albanian]; (b) Spontaneously chatting in the street with a Kosovo Serb [Albanian]; (c) Have a Kosovo Serb [Albanian] as guest at your home; (d) Work together with a Kosovo Serb [Albanian]; (e) Live in the same city as a Kosovo Serb [Albanian]; (f) Have a Kosovo Serb [Albanian] as your next-door neighbour; (g) Have a Kosovo Serb [Albanian] as your close friend; (h) Have your child play together with a Kosovo Serb [Albanian] child $(1=$ not at all acceptable, $7=$ very acceptable $)$. All items loaded on one factor and formed reliable scales $\left(\alpha_{\text {Albanians }}=.94, \alpha_{\text {Serbs }}=.94\right)$.

Feelings towards the ethnic outgroup were measured with a feeling thermometer where participants rated how cold or warm they felt towards their ethnic outgroup $(0=$ cold, $100=$ warm; adapted from Schmid et al., 2009). Despite being single-item measures, feeling thermometers have been shown to reliably assess feelings towards groups (Lavrakas, 2008).

\section{Results}

Table 1 reports descriptive results and $t$ tests on mean group differences for all variables. Table 2 reports all correlations for main study variables that were tested in the theoretical model. In the 
Table 1. Descriptive statistics and $t$ tests of group mean differences on main variables.

\begin{tabular}{|c|c|c|c|c|c|c|c|}
\hline Variable & $\begin{array}{l}\text { Albanians } \\
M(S D)\end{array}$ & $N$ & $\begin{array}{l}\text { Serbs } \\
M(S D)\end{array}$ & $N$ & $\begin{array}{l}95 \% \text { CI for } \\
\text { mean difference }\end{array}$ & $t$ test & $d f$ \\
\hline \multicolumn{8}{|l|}{ Social identity } \\
\hline Ethnic identification & $5.63(1.39)$ & 211 & $5.47(1.33)$ & 93 & {$[-0.17,0.50]$} & .96 & 302 \\
\hline National identification & $5.72(1.39)$ & 211 & $3.99(1.81)$ & 94 & {$[1.31,2.14]$} & $8.23^{* * *}$ & 144.15 \\
\hline Overlap complexity $^{a}$ & $4.71(1.48)$ & 198 & $5.95(1.73)$ & 110 & {$[-1.62,-0.86]$} & $6.44 * * *$ & 190.80 \\
\hline Similarity complexity ${ }^{\mathrm{b}}$ & $3.84(1.39)$ & 216 & $4.05(0.13)$ & 100 & {$[-0.54,0.10]$} & -1.33 & 203.06 \\
\hline \multicolumn{8}{|l|}{ Identity-based threat } \\
\hline Distinctiveness threat & $4.62(1.98)$ & 198 & $5.46(1.60)$ & 81 & {$[-1.29,-0.40]$} & $-3.72^{* * *}$ & 183.29 \\
\hline \multicolumn{8}{|l|}{ Intergroup outcomes } \\
\hline Interethnic contact & $1.70(1.07)$ & 204 & $3.07(1.87)$ & 89 & {$[-1.95,-1.11]$} & $-7.19^{* * *}$ & 113.86 \\
\hline Readiness to contact outgroup & $3.43(1.67)$ & 202 & $3.60(1.70)$ & 87 & {$[0.88,1.60]$} & -.77 & 287 \\
\hline Feelings towards outgroup & $24.03(25.71)$ & 198 & $27.32(30.55)$ & 82 & {$[-10.33,3.74]$} & -.92 & 278 \\
\hline
\end{tabular}

Note. All variables were measured on a 7-point scale, except for feelings towards outgroup (0-100 scale) and overlap complexity (1-11 point scale).

a, bHigher scores indicate higher social identity complexity (less identity overlap, less identity similarity).

${ }^{*} p<.05 .{ }^{* *} p<.01 .{ }^{* * *} p<.001$.

Table 2. Correlations between main variables for Study 1 (Albanians) and Study 2 (Serbs).

\begin{tabular}{lccccccc}
\hline Variable & 1 & 2 & 3 & 4 & 5 & 6 & 7 \\
\hline 1. Ethnic identification & - & .04 & $-.24^{*}$ & -.12 & $.38^{* * *}$ & $-.37^{* *}$ & -.15 \\
2. National identification & $.78^{* * *}$ & - & $-.40^{* * *}$ & $-.55^{*}$ & -.09 & $.21^{\dagger}$ & $.20^{\dagger}$ \\
3. Overlap complexity & $-.30^{* * *}$ & $-.32^{* * *}$ & - & $.57^{* *}$ & -.04 & .01 & -.05 \\
4. Similarity complexity & $-.49^{* *}$ & $-.39^{* *}$ & $.45^{* *}$ & - & .09 & $-.27^{*}$ & -.12 \\
5. Distinctiveness threat & $.23^{* *}$ & $.25^{* * *}$ & $-.23^{* *}$ & $-.26^{* *}$ & - & $-.50^{* * *}$ & $-.32^{* *}$ \\
6. Feelings towards outgroup & $-.18^{* *}$ & $-.15^{*}$ & .06 & .02 & $-.39^{* * *}$ & - & $.45^{* * *}$ \\
7. Readiness to contact outgroup & $-.15^{*}$ & $-.17^{*}$ & $.21^{* *}$ & $.14^{*}$ & $-.47^{* * *}$ & $.62^{* * *}$ & - \\
\hline
\end{tabular}

Note. Below the diagonal are correlations for Albanians; above the diagonal, those for Serbs.

${ }^{*} p<.05 .{ }^{* *} p<.01 .{ }^{* * *} p<.001 .{ }^{\dagger} p \leqslant .06$.

following section we describe these results structured by the predictions we made.

\section{How Strongly Do Albanians and Serbs Identify With Their Ethnicity and Nationality?}

In line with Hypotheses 1 and 2, the results showed that both groups had strong ethnic identification but differed in their identification with the new national identity. As predicted, for the Kosovar Albanian majority, referring to Kosovars or to Albanians implied the same identity. That is, Albanians showed equally high ethnic and national identification (see Table 1). Moreover, the levels of identification with the ethnic and national groups were highly correlated $r(198)=.78, p<.001$ (see Table 2), suggesting that Kosovar Albanian participants indeed projected their ethnic identity onto their national identity. This is also suggested by the negative associations that both of these identities have with feelings towards Serbs and readiness to have contact with them.

For Kosovar Serb participants, a very different picture emerged. Although their level of ethnic identification was comparable to that of Kosovar Albanians, their identification with the Kosovar 
national identity was significantly lower. Moreover, consistent with previous studies among ethnic minority groups finding negative or no relationship between these identities (e.g., Sidanius et al., 1997; Sinclair et al., 1998; Verkuyten \& Martinovic, 2012) and in contrast to Albanians, for Kosovar Serbs no relationship was found between ethnic and national identification. Taken together, these findings suggest that ethnic and national identities were perceived as separate constructs by the Serbs in our sample. Interestingly, for Serbs there was evidence of a marginally positive relationship between superordinate (national) identification and evaluations of the outgroup. This suggests that, for them, stronger identification with Kosovo predicted more positive feelings towards Albanians and more readiness to have contact with them. Similarly to Albanians, Serbs' ethnic identification predicted negative feelings towards outgroup members. No significant effects were found for readiness to have contact with Albanians.

\section{How Complex Are Social Identities of Kosovar Albanians and Kosovar Serbs?}

As hypothesized (see H3), Kosovar Albanian (majority) participants showed significantly lower overlap complexity (or more identity overlap) than Kosovar Serb (minority) participants did (see Table 1). However, although identity overlap and identity similarity were significantly correlated in both groups, Kosovar Albanians and Serbs did not differ significantly in similarity complexity.

The difference we found on overlap complexity between the two groups stands in contrast to earlier findings on majority-minority groups using the same 11-point scale (e.g., Brewer et al., 2013), which showed a higher identity overlap for minority members $(M=6.48, S D=1.01) \mathrm{com}^{-}$ pared to members of the majority group in Australia $(M=5.98, S D=1.04)$. However, numerical differences between ethnic groups in Australia are smaller compared to Kosovo and the studies there were conducted in (university) contexts where the Asian Australian minority group is often proportionally overrepresented. To further examine overlap differences in our samples, we compared the means of all 12 ingroup pairings separately (see Table 3). Results show that, for Albanians, national and ethnic identities indeed overlapped the most, whereas for Serbs, these two identities were among the least overlapping ones compared to all other ingroup combinations.

As expected and in line with previous work showing positive effects for complexity (Brewer \& Pierce, 2005; K. P. Miller et al., 2009; Roccas \& Brewer, 2002; Xin et al., 2016), correlations revealed that higher SIC (both overlap and similarity) was associated with more readiness to have contact with outgroup members for members of the Albanian majority (see Brewer et al., 2013, Study 2 , for similar findings). However, this effect was not found among the Serb minority participants. The absence of this relationship for Serb participants is consistent with previous work that found no relationship between complexity and inclusiveness of outgroups for minority members (Brewer et al., 2013, Study 2).

Being high in both types of SIC was associated with less distinctiveness threat among Albanian participants, whereas for Serbs, SIC was unrelated to distinctiveness threat. Moreover, no significant correlations were found between either form of identity complexity and feelings towards outgroup members among Albanian participants. For Serbs, however, higher similarity complexity was negatively associated with feelings towards outgroup members so that, for Serbs, higher perceived similarity between the group prototypes (indicating lower identity complexity) actually allowed them to feel more positive towards Albanians, possibly because they perceived more commonalities between their ethnic and national identities (see Ufkes, Otten, van Der Zee, Giebels, \& Dovidio, 2012, for a similar argument with urban district identity).

Finally, results revealed that strong identification with nationality and ethnicity was negatively related to SIC, so that Albanians and Serbs with more complex identities (in terms of identity overlap) were less likely to report high identification with their nationality and their ethnicity. Among 
Table 3. Descriptive statistics and $t$ tests for differences in pairs of overlap scores.

\begin{tabular}{|c|c|c|c|c|c|c|c|}
\hline \multirow[t]{3}{*}{ Measure } & \multicolumn{4}{|c|}{ Group } & \multirow[t]{3}{*}{$95 \% \mathrm{CI}$} & \multirow[t]{3}{*}{$t$ test } & \multirow[t]{3}{*}{$d f$} \\
\hline & \multicolumn{2}{|c|}{ Albanians } & \multicolumn{2}{|c|}{ Serbs } & & & \\
\hline & $M(S D)$ & $N$ & $M(S D)$ & $N$ & & & \\
\hline Nationality and ethnicity & $8.44(1.94)$ & 221 & $5.26(2.62)$ & 110 & {$[2.64,3.75]$} & $11.32^{* * *}$ & 170.25 \\
\hline Nationality and Group 1 & $7.56(1.99)$ & 220 & $5.24(2.49)$ & 106 & {$[1.78,2.87]$} & $8.44^{* * *}$ & 171.40 \\
\hline Nationality and Group 2 & $7.21(2.12)$ & 220 & $5.73(2.69)$ & 105 & {$[0.89,2.07]$} & $4.96^{* * *}$ & 167.40 \\
\hline Ethnicity and Group 1 & $7.01(2.02)$ & 220 & $7.67(2.43)$ & 104 & {$[-1.20,1.12]$} & $-2.39 *$ & 172.46 \\
\hline Ethnicity and Group 2 & $6.81(2.14)$ & 218 & $6.70(2.66)$ & 104 & {$[-0.48,0.70]$} & 0.36 & 168.97 \\
\hline Group 1 and Group 2 & $6.66(2.35)$ & 217 & $5.97(2.36)$ & 102 & {$[0.14,1.25]$} & $2.45^{*}$ & 317 \\
\hline
\end{tabular}

Note. Overlap scale ranges from 1 (none are) to 11 (all of them are), more overlap means less complex social identity. $* p<.05 . * * p<.01 . * * * p<.001$.

Albanians, but not Serbs, this negative relationship between identification and SIC was also found for similarity complexity.

To conclude, the results indicate that, in line with previous findings (Brewer et al., 2013; Brewer \& Pierce, 2005), higher identity complexity was consistently related to more positive outcomes for intergroup attitudes in the Kosovar context, but only for the Albanian majority.

\section{What Is the Extent of Group Segregation and Are There Opportunities for Reconciliation?}

Results confirmed that the groups under consideration here are indeed segregated. We found that contact among groups is generally low, with Serbs as the minority reporting having more contact with Albanians than vice versa (see Table 1). The extent to which there is no contact at all for members of the majority group is worrisome. Fiftytwo percent of Albanian participants reported that they never had contact with a member from the Serb community, while only $12 \%$ of Serbs reported that they never had contact with Albanians. More importantly, neither Albanian nor Serb participants displayed readiness to have contact with outgroup members (e.g., talking in the street, being neighbours or friends, etc.). Interethnic contact and readiness to have contact with outgroup members were both measured as contact variables. However, because there was so little contact between groups, the subsequent analyses focus on the readiness to have contact with members of the outgroup. In terms of affect, groups were equally cold towards one another (average 24-27 on a 100-point feeling thermometer). Taken together, these results suggest that not only is there little contact between the groups, but there is also high reluctance to improve the strenuous relations.

\section{Do Albanians and Serbs Experience Distinctiveness Threat?}

We found relatively high levels of distinctiveness threat in both groups, with Serb (minority) participants reporting significantly higher threat $\left(M_{\text {Albanians }}=4.68, S D=1.98 ; M_{\text {Serbs }}=5.46\right.$, $S D=1.60$; see Table 1). Comparing these findings with previous work shows that the reported levels of distinctiveness threat are very high compared to similar studies that measured distinctiveness threat using the same scale among segregated groups (e.g., Schmid et al., 2009, with Catholics and Protestants in Northern Ireland), where the average scores were much lower (Study 1: $M=$ $1.68, S D=1.54$; Study 2: $M=1.88, S D=0.85$ ). This suggests that, in the current intergroup setting, distinctiveness threat is an important type of threat that needs to be addressed in order for intergroup relations to be improved. 


\section{Testing the Theoretical Model}

To test the hypothesized model (see Figure 2), where less distinctiveness threat is predicted by higher SIC and lower ethnic identification, and to examine whether distinctiveness threat in turn negatively mediates the relationships between these identity processes and intergroup outcomes, we ran path analyses by entering all specified variables as observed variables. Complexity and ethnic identification were entered as predictor variables, distinctiveness threat was a mediator, and feelings towards outgroup and readiness to have contact with outgroup members were criterion variables. The model was analyzed in MPlus (Version 7.4; Muthén \& Muthén, 2015) using maximum likelihood estimation (ML). We examined our model fits with a chi square test, the comparative fit index (CFI) as an index of incremental fit, the root means square error of approximation (RMSEA) and standardized root means squared residual (SRMR) as indexes of absolute fit. A good fit as suggested by $\mathrm{Hu}$ and Bentler (1999) is indicated by a nonsignificant chi square value, a $\mathrm{CFI} \geqslant .95$, RMSEA $\leqslant .06$, and SRMR $\leqslant .08$. However, a RMSEA $\leqslant .08$ and a $\mathrm{CFI} \geqslant .90$ have also been argued to indicate adequate model fit (Browne \& Cudeck, 1992).

To test whether the model works for both Kosovar Albanians and Kosovar Serbs, we first ran a baseline model with no constraints on group equality. Because we measured SIC via two of its subcomponents, we entered both as complexity predictors in the model (along with ethnic identification). This model did not show good fit, $\chi^{2}(12)=27.51, p=.01, \chi^{2} / d f=2.29, \mathrm{CFI}=$ .93, RMSEA $=.09$, SRMR $=.04$. Because of the strong correlation between the two indicators of SIC, we next tested two baseline models with ethnic identification and each complexity measure separately, with no constraints on group equality. The model with similarity complexity did not show good fit, $\chi^{2}(8)=20.58, p=.008$, $\chi^{2} / d f=2.57$, CFI $=.94$, RMSEA $=.10$, SRMR $=.04$. However, the model with overlap complexity did show good fit to the data, $\chi^{2}(8)=13.21$, $p=.11, \chi^{2} / d f=1.65$, CFI $=.98$, RMSEA $=.06$,
SRMR $=.04$. We therefore decided to focus exclusively on overlap complexity as indicator for SIC.

We next examined whether structural paths in the model were equal across the groups by placing equality constraints on all structural parameters. This model, however, fitted the data significantly worse, $\chi^{2}(13)=24.82, p=.024$, $\chi^{2} / d f=2.99, \mathrm{CFI}=.95, \mathrm{RMSEA}=.08, \mathrm{SRMR}$ $=.06, \Delta \chi^{2}(5)=11.62, p=.04$. In order to improve the model, we next tested individual parameters for equality using Wald tests. We detected two unequal parameters across groups. First, there was a marginally significant difference between Kosovar Albanian and Kosovar Serb participants with regard to the path between overlap complexity and distinctiveness threat, $\Delta \chi^{2}(1)=3.60, p=.06$, where overlap complexity was negatively associated with distinctiveness threat for Kosovar Albanians $(\beta=-0.17, p=$ $.01)$, while this relationship was not significant for Kosovar Serbs $(\beta=-0.03, p=.78)$. The second unequal parameter was the one predicting feelings towards the outgroup by distinctiveness threat, $\Delta \chi^{2}(1)=5.20, p=.02$. Here, the effect of distinctiveness threat on feelings towards the outgroup was significantly larger for Kosovar Serb participants $(\beta=-0.50, p<.001)$ than for Kosovar Albanian participants $(\beta=-0.38, p<$ $.001)$. We then ran a model where the paths predicting distinctiveness threat by overlap complexity and the paths predicting feelings towards outgroup by distinctiveness threat were free to vary across groups. This nested model showed good fit, $\chi^{2}(11)=15.17, p=.17, \chi^{2} / d f=1.38$, $\mathrm{RMSEA}=.05, \mathrm{CFI}=.98, \mathrm{SRMR}=.05$, and was as good as the baseline model with no cross-group equality constraints, $\Delta \chi^{2}(3)=1.96, p=.58$ (see Figure 3 for path analysis). However, given that the nested model had fewer estimated parameters (i.e., was more parsimonious), it was our preferred one. The model explained $9.8 \%$ and $8.4 \%$ of variance in distinctiveness threat for Kosovar Albanians (majority) and Kosovar Serbs (minority), respectively; $14.5 \%$ and $25.2 \%$ of variance in feelings towards outgroup, respectively; and $21.3 \%$ and $12 \%$ in readiness to have contact with 


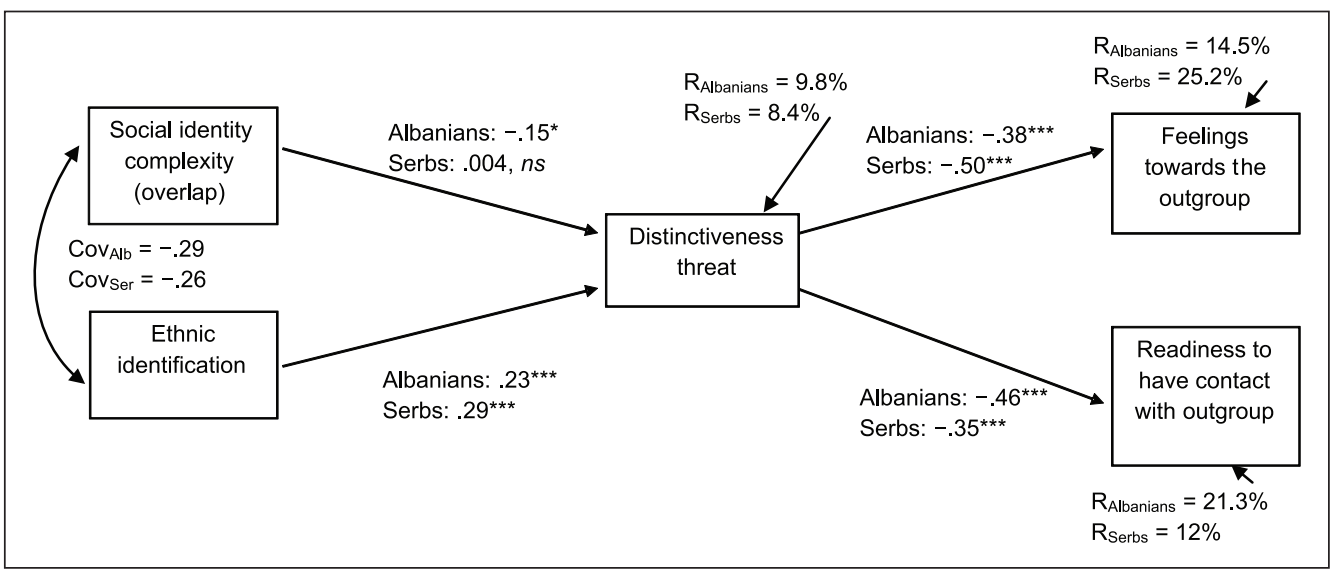

Figure 3. Path analysis model showing relationships between observed variables (Study 1 Albanians: $N=221$; Study 2 Serbs: $N=110)$.

Note. Path coefficients are standardized beta weights. Model fit $\chi^{2}(11)=15.17, p=.17, \chi^{2} / d f=1.38$, RMSEA $=.05$, $\mathrm{CFI}=.98, \mathrm{SRMR}=.05$.

$* p<.05 . * * p<.01 . * * * p<.001$.

members of the outgroup, respectively. There were no modification indices suggested to be added to this model.

In line with our theoretical model (H4), results revealed that for both Kosovar Albanians and Kosovar Serbs, higher ethnic identification predicted more distinctiveness threat $\left(\beta_{\text {Albanians }}=\right.$ $\left.0.23, p<.001 ; \beta_{\text {Serbs }}=0.29, p<.001\right)$. Additionally, in line with our predictions (H4), we also found that for Albanians (but not for Serbs), a higher complexity in identity overlap predicted less distinctiveness threat $\left(\beta_{\text {Albanians }}=-0.15, p=\right.$ .025). While the sources of distinctiveness threat differed between groups, the relationships between distinctiveness threat and intergroup outcomes were similar across the groups. For Kosovar Albanians and Kosovar Serbs in our samples, more distinctiveness threat predicted more negative feelings towards the outgroup $\left(\beta_{\text {Albanians }}\right.$ $\left.=-0.38, p<.001 ; \beta_{\text {Serbs }}=-0.50, p<.001\right)$ as well as less readiness to have contact with the outgroup $\left(\beta_{\text {Albanians }}=-0.46, p<.001 ; \beta_{\text {Serbs }}=-0.35\right.$, $p<.001)$. Importantly, the relationships between identity processes (i.e., ethnic identification for Serbs, and ethnic identification as well as identity complexity for Albanians) and intergroup outcomes (i.e., feelings towards the outgroup and readiness to have contact with members of the outgroup) were significantly mediated by distinctiveness threat.

Alternative models. To consider whether other models are plausible with our data, we tested two alternative models. Given that previous work examined distinctiveness threat as a predictor of complexity (see Schmid et al., 2009), we tested whether this reverse relationship between complexity and threat fitted the data. We tested a model where ethnic identification predicted feelings towards the outgroup and readiness to have contact with the outgroup, with distinctiveness threat and SIC (overlap) as successive mediating mechanisms. The model did not show acceptable fit at baseline level, that is, with no equality constraints on the groups, $\chi^{2}(10)=100.08$, $p<.001, \chi^{2} / d f=10.01, \mathrm{CFI}=.62, \mathrm{RMSEA}=.24$, SRMR $=.15$. Alternatively, another line of research has identified affect to be an important predictor of readiness to have contact (Esses \& Dovidio, 2002; Stangor, Sullivan, \& Ford, 1991). Given that, in our studies, feelings towards the outgroup and readiness to have contact were highly correlated $\left(r_{\text {Albanians }}=.62, p<.001 ; r_{\text {Serbs }}=\right.$ $.45, p<.001$; see Table 2 ), we tested a model 
similar to the first one, where both identity processes (ethnic identification and overlap SIC) predicted readiness to have contact, but were mediated sequentially by distinctiveness threat and feelings towards members of the outgroup. This baseline model also did not show satisfactory fit, $\chi^{2}(10)=35.63, p<.001, \chi^{2} / d f=3.56$, $\mathrm{CFI}=.88, \mathrm{RMSEA}=.12, \mathrm{SRMR}=.06$.

Taken together, these results suggest that there are different mechanisms that predict intergroup outcomes for Albanians and Serbs in Kosovo. For the Kosovar Serb minority group, ethnic identification is the only source of distinctiveness threat, while for the Kosovar Albanian majority, threat is predicted by both high ethnic identification and low complexity of their identities. Moreover, distinctiveness threat mediated the relationship between these identity processes and intergroup outcomes among these groups.

\section{Discussion}

The goal of these two correlational studies was to examine the opportunities that social identity models offer to predict interethnic relations in a segregated postconflict context like Kosovo, where a new national identity is currently developing. Using insights from work on superordinate categorization (e.g., Gaertner \& Dovidio, 2000), social identity complexity (Roccas \& Brewer, 2002), and distinctiveness threat (Jetten et al., 2001) we were able to shed light on these processes and point out the similarities and differences among majority and minority group members. Importantly, we reveal which process best predicts the readiness to have outgroup contact - an understudied perspective in contact literature (Ron, Solomon, Halperin, \& Saguy, 2016).

First, we show that consistent with previous work (Brewer et al., 2013), SIC has different implications for majority and minority members. It was found to be an important variable in predicting more positive intergroup relations for the Albanian majority group. Kosovar Albanians are low in SIC (i.e., perceive ethnic and national identity to be highly overlapping and similar), but a more complex identity for them predicts improved evaluations of Kosovar Serbs. This replicates previous findings on identity complexity, which consistently show that being higher in SIC makes people cognitively aware of the differences that exist between social groups, leading them to become more inclusive in their ingroup composition (Brewer \& Pierce, 2005; Roccas \& Brewer, 2002). In the current setting, this result is especially helpful given that superordinate (national) identity does not yet function as an inclusive identity for this group. Consistent with previous work on ingroup projection (Mummendey \& Wenzel, 1999; Waldzus \& Mummendey, 2004), Albanians essentially perceive Kosovar identity to be an extension of their (Albanian) ethnic identity and is therefore not inclusive of Serbs. However, those Albanians who have established a more complex identity do report less distinctiveness threat and more positive attitudes towards the outgroup. Being higher in SIC is also related to lower national and ethnic identification.

Unlike previous correlational research (e.g., Schmid et al., 2009) showing that lower distinctiveness threat predicts more complex identities, we show a reverse relationship between the two. However, as we have argued, in Schmid et al.'s (2009) Northern Irish study, participants showed more intergroup contact to begin with, while in our samples as much as half of the Albanian majority group members had never had any sort of contact with a Serb. Our work shows that in segregated intergroup contexts like Kosovo where opportunities for contact are scarce or absent, people with higher SIC are less concerned about the distinctiveness of their ethnic group and therefore more ready to have outgroup contact.

For Serb minority members, on the other hand, who show higher identity complexity than Albanians in our study in the sense that they perceive less overlap between their ethnic and national identities, the relationship between complexity and outgroup evaluations was absent. This finding is consistent with previous work that found no relationship between complexity and inclusiveness of outgroups for minority members (Brewer et al., 2013, Study 2). 
Second, we show that while the Albanian majority and the Serb minority differ in the extent of identity overlap, they show no differences in how similar they think the prototypes of their ethnic and national groups are (i.e., similarity complexity). Given the large numerical group differences, one could argue that the difference found in overlap is simply an objective reflection of group proportions in Kosovo and expect similarity complexity to represent a stronger measure for SIC instead. However, our findings suggest that this is not the case. While being high in both types of SIC shows similar associations with outgroup attitudes among Albanian majority participants, it is overlap complexity and not similarity that predicts outgroup attitudes via distinctiveness threat for this majority group in the Kosovar context. It seems that in contexts like Kosovo where national prototypes are still emerging and where groups have large numerical differences, overlap complexity renders as a more meaningful aspect of SIC for members of the majority group. The complexity issue for this ethnic group is more about defining the composition of national identity and setting group boundaries (i.e., consider whether Serbs belong to the Kosovar identity or not) than about the prototypicality or the meaning of these identities (similarity complexity). This contrasts with a study in Northern Ireland (Schmid, Hewstone, \& Tausch, 2014) where similarity complexity turned out to be a somewhat stronger complexity predictor of outgroup attitudes among groups of similar proportions. However, groups in Northern Ireland are objectively constrained to exclude outgroup members from the national group so that they might compete for prototypicality instead. In Kosovo, excluding others is cognitively easier to do for the majority group given the large numerical differences and the evident group segregation.

More work needs to be done to fully understand the SIC components independently, their asymmetries and implications for majority and minority groups. For example, unlike our findings, previous work in multicultural contexts where the minority is numerically more represented and ethnic groups have more opportunities for intergroup contact (Brewer et al., 2013) showed opposite mean levels of overlap complexity, with minority reporting lower SIC compared to majority. Also, in contrast to our findings, previous research showed that lower SIC related to lower (not higher) national identification among the Turkish minority group in the Netherlands (Verkuyten \& Martinovic, 2012, Study 1). However, the SIC measure in this earlier study examined overlap between ethnic and religious identities and did not examine the complexity of national identity as we do here.

Third, our findings suggest that in the current identity-building process, both groups show a central concern for the distinctiveness of their ethnic identity, with the Serb minority showing a more pronounced perception of threat (as is often the case with minority groups; Jetten et al., 2004). The reported levels of this type of threat in both of our samples were very high compared to other similar studies that measured distinctiveness threat in divided contexts (e.g., Schmid et al., 2009). In support of earlier work (Branscombe et al., 1999; Jetten et al., 2001; Riek et al., 2006), we show that the more distinctiveness threat that is perceived by majority and minority groups, the more negative intergroup outcomes will be. This is problematic given the already troubled intergroup relations, as perceptions of threat can lead to an intensification of ethnicidentities (Jetten et al., 2001). Importantly, we show that distinctiveness threat mediates the relationship between identity and evaluations of the outgroup. Finding ways to reduce threat is essential for functional relations. The current results suggest that lower distinctiveness threat is predicted by more complex identities for the Albanian majority (but not the Serb minority), so this could be a possible avenue for intervention in this group. One contextual predictor of SIC is intergroup contact and diversity of the social environment (Brewer \& Pierce, 2005; Roccas \& Brewer, 2002; Schmid et al., 2013). Although contact is limited in Kosovo, in future work we aim to examine SIC among Albanians who are living in less segregated settings in which they have more opportunities for contact with Serbs. 
For the minority group of Serbs, threat is predicted only by ethnic identification. Past work has found that minority members can cope with identity-based threats by increased ingroup (ethnic) identification and by distancing from the majority group (Verkuyten \& Yildiz, 2007). Moreover, they could resist identifying with the superordinate identity as they perceive they would have to give up their subgroup identity if they did so (van Leeuwen et al., 2003). Therefore, supporting minority group members' need for a distinctive subgroup identity by valuing it more explicitly can make them feel they are part of the superordinate (Kosovar) category (Hornsey $\&$ Hogg, 2000). Work on dual identities (Dovidio et al., 2007) has shown that simultaneously emphasizing both ethnic and national identities maintains subgroup distinctiveness while creating a positive relation to the superordinate identity. This approach is especially valuable in situations when majority-minority group differences are large (Gonzales \& Brown, 2006), as they are in Kosovo.

Given that our results point to a crucial role of distinctiveness threat in predicting intergroup relations, future work should examine the effectiveness of interventions that aim to reduce distinctiveness threat among Albanians and Serbs in Kosovo. One way of reducing threats to the positive distinctiveness of the group may be by explicitly affirming group identity in a different way, for example, by giving Albanians and Serbs positive feedback about the distinctiveness of their groups (Derks, van Laar, \& Ellemers, 2006, 2007). Work on group affirmation (Derks, van Laar, \& Ellemers, 2009; Sherman, Kinias, Major, Kim, \& Prenovost, 2007) shows that inducing people to affirm their social identity by focusing on positive aspects of their group (e.g., reflecting on important qualities or values that characterize their group) can help them feel their identity is protected against threats and reduce the need to express negative outgroup attitudes as a way of maintaining their positive distinctiveness (Derks, Scheepers, van Laar, \& Ellemers, 2011; Villicana, Rivera, \& Garcia, 2017). Future work should establish whether group affirmation interventions could also reduce distinctiveness threat among Albanians and Serbs in Kosovo.

The current results also have their limitations. While recognizing the difficulties that are associated with doing research with segregated groups on sensitive topics that represent the very basis of the conflict discourse, these are correlational studies and we cannot speak about the directionality of our effects. Also, they were conducted with student samples, which limit their generalization. Further research on SIC needs to be more versatile in research design, especially experimental and longitudinal, to address causality and shed light on the development of complex identities among natural groups like these.

\section{Conclusion}

This research shows that while different processes lead up to affective and behavioral outgroup evaluations (ethnic identification for minority group members; overlap complexity and ethnic identification for majority group members), distinctiveness threat is the central concern for both groups. This identity-based threat is effectively predicted by overlap complexity (not similarity) among members of the majority group when a new superordinate identity is introduced. For minority members, however, threat is predicted only by ethnic identification. The findings highlight the importance of distinctiveness threat when groups have to negotiate old ethnic identities and new superordinate (national) ones, as it mediates the process between identification and intergroup evaluations, namely feelings towards outgroup members and readiness to establish contact with them. More work is needed to understand the circumstances that help in developing more complex identities in segregated settings like Kosovo and the asymmetries that each complexity component has for majority and minority groups. Also, additional work needs to examine the mechanisms that could reduce distinctiveness threat among minority group members (e.g., group affirmation or dual identities). 


\section{Funding}

This work is supported by a $\mathrm{PhD}$ grant awarded to the first author by the Netherlands Fellowship Programme (award reference number 13/324). We thank Oliver Tošković for his help in collecting data from Kosovar Serbs in North Mitrovica.

\section{Notes}

1. This majority-minority representation is based on estimates of the European Centre for Minority Issues Kosovo (ECMI Kosovo, 2013). It combines data from the population census 2011 and a number of other relevant sources given that the census is incomplete; it has been boycotted by Serbs living in enclaves north of Kosovo and partially boycotted by Serbs in the southern part of the country. Population statistics are highly sensitive and should be taken with caution.

2. Kosovo became independent in 2008, following international military intervention in 1999 that ended the conflict and a period of political protectorate by a United Nations' mission (UNMIK).

3. We did not include national identification in the model because there was a very high correlation between ethnic and national identities for Albanians $(r=.78, p<.001)$, so including them both would have raised issues of collinearity.

4. This study included only an Albanian sample and measured ingroup identification as identification with "Albanians in Kosovo," while the superordinate identity was measured as identification with "inhabitants of the territory of Kosovo." In our studies, we explicitly measured social identification "with Albanians" (as a broad ethnic/ cultural identity, not specific to Kosovo's region) and superordinate identity as "identifying with Kosovars" (to specifically imply the newly developed national identity, not just the territory).

5. We also measured the cognitive aspect of intergroup relations, including content of stereotypes and perceptions of group status. However, these measures are reported in another manuscript, currently in preparation.

6. Because Kosovar identity is an emerging identity, asking for national identification might have led participants to indicate identification with ethnic identities or identification with neighbouring states where their ethnic group is a majority (e.g., Serbia for Serbs). Therefore, an emphasis on the passport was added to specifically elicit the new Kosovar national identity.

\section{ORCID iD}

Colette van Laar (iD) https://orcid.org/0000-00028113-1242

\section{References}

Allport, G. W. (1954). The nature of prejudice. Cambridge, MA: Addison Wesley.

Andrighetto, L., Mari, S., Volpato, C., \& Behluli, B. (2012). Reducing competitive victimhood in Kosovo: The role of extended contact and common ingroup identity. Political Psychology, 33, 513-529. doi:10.1111/j.14679221.2012.00887.x

Ashmore, R. D., Deaux, K., \& McLaughlin-Volpe, T. (2004). An organizing framework for collective identity: Articulation and significance of multidimensionality. Psychological Bulletin, 130, 80-114. doi:10.1037/0033-2909.130.1.80

Bettencourt, B. A., Dorr, N., Charlton, K., \& Hume, D. L. (2001). Status differences and in-group bias: A meta-analysis examination of the effects of status stability, status legitimacy, and group permeability. Psychological Bulletin, 127, 520-542. doi:10.1037/0033-2909.127.4.520

Bizman, A., \& Yinon, Y. (2001). Perceived threat and Israeli Jews' evaluations of Russian immigrants: The moderating role of Jewish and Israeli identity. International Journal of Intercultural Relations, 25, 691-704. doi:10.1016/s0147-1767(01)00033-5

Blair, I. V., Park, B., \& Bachelor, J. (2003). Understanding intergroup anxiety: Are some people more anxious than others? Group Processes \& Intergroup Relations, 6, 151-169. doi:10.1177/1368430203006002002

Branscombe, N. R., Ellemers, N., Spears, R., \& Doosje, B. (1999). The context and content of social identity threat. In N. Ellemers, R. Spears, \& B. Doosje (Eds.), Social identity: Context, commitment, content (pp. 35-58). Oxford, UK: Blackwell.

Brewer, M. B. (1979). In-group bias in the minimal intergroup situation: A cognitive motivational analysis. Psychological Bulletin, 86, 307-324. doi:10.1037/0033-2909.86.2.307

Brewer, M. B. (2010). Social identity complexity and acceptance of diversity. In R. J. Crisp (Ed.), The psychology of social and cultural diversity (pp. 12-33). Chichester, UK: Wiley Blackwell.

Brewer, M. B., Gonsalkorale, K., \& van Dommelen, A. (2013). Social identity complexity: Comparing majority and minority ethnic group members in a multicultural society. Group Processes \& Intergroup Relations, 16, 529-544. doi:10.1177/ 1368430212468622 
Brewer, M. B., \& Pierce, K. P. (2005). Social identity complexity and outgroup tolerance. Personality and Social Psychology Bulletin, 31, 428-437. doi:10.1177/0146167204271710

Brown, R. (1995). Prejudice: Its social psychology. Oxford, UK: Blackwell.

Brown, R. (2000). Social identity theory: Past achievements, current problems and future challenges. European Journal of Social Psychology, 30, 745-778. doi:10.1002/ 1099-0992(200011/12)30:6<745::AID EJSP24>3.0.CO;2-O

Browne, M. W., \& Cudeck, R. (1992). Alternative ways of assessing model fit. Sociological Methods \& Research, 21, 230-258. doi:10.1177/0049124192021002005

Cronin, T. J., Levin, S., Branscombe, N. R., van Laar, C., \& Tropp, L. R. (2012). Ethnic identification in response to perceived discrimination protects well-being and promotes activism: A longitudinal study of Latino college students. Group Processes \& Intergroup Relations, 15, 393-407. doi:10.1177/1368430211427171

Daskalovski, Z. (2003). Claims to Kosovo: Nationalism and self-determination. In F. Bieber \& Z. Daskalovski (Eds.), Understanding the war in Kosovo (pp. 11-28). London, UK: Routledge.

Derks, B., Scheepers, D., van Laar, C., \& Ellemers, N. (2011). The threat vs. challenge of car parking for women: How self- and group affirmation affect cardiovascular responses. Journal of Experimental Social Psychology, 47, 178-183. doi:10.1016/j. jesp.2010.08.016

Derks, B., van Laar, C., \& Ellemers, N. (2006). Striving for success in outgroup settings: Effects of contextually emphasizing ingroup dimensions on stigmatized group members' social identity and performance styles. Personality and Social Psychology Bulletin, 32, 576-588. doi:10.1177/0146167205283336

Derks, B., van Laar, C., \& Ellemers, N. (2007). Social creativity strikes back: Improving motivated performance of low status group members by valuing ingroup dimensions. European Journal of Social Psychology, 37, 470-493. doi:10.1002/ejsp.375

Derks, B., van Laar, C., \& Ellemers, N. (2009). Working for the self or working for the group: How self- versus group affirmation affects collective behavior in low-status groups. Journal of Personality and Social Psychology, 96, 183-202. doi:10.1037/ a0013068

Devos, T., \& Banaji, M. R. (2005). American = White? Journal of Personality and Social Psychology, 88, 447466. doi:10.1037/0022-3514.3.447
Dovidio, J. F., Gaertner, S. L., \& Saguy, T. (2007). Another view of "we": Majority and minority group perspectives on a common ingroup identity. European Review of Social Psychology, 18, 296330. doi:10.1080/10463280701726132

Dovidio, J. F., Gaertner, S. L., \& Saguy, T. (2009). Commonality and the complexity of "we": Social attitudes and social change. Personality and Social Psychology Review, 13, 3-20. doi:10.1177/ 1088868308326751

Ellemers, N., Spears, R., \& Doosje, B. (2002). Self and social identity. Annual Review of Psychology, 53, 161186. doi:10.1146/annurev.psych.53.100901.135228

Esses, V. M., \& Dovidio, J. F. (2002). The role of emotions in determining willingness to engage in intergroup contact. Personality and Social Psychology Bulletin, 28, 1202-1214. doi:10.1177/01461672022812006

European Centre for Minority Issues Kosovo (ECMI Kosovo). (2013). Communities in Kosovo: A guidebook for professionals working with communities in Kosovo. Retrieved from http://www.ecmikosovo.org/ uploads/ECMIKosovoDec2013GuidebookforProfessionalsENG.pdf

Gaertner, S. L., \& Dovidio, J. F. (2000). Reducing intergroup bias: The common ingroup identity model. Philadelphia, PA: Psychology Press.

Gaertner, S. L., Dovidio, J. F., Anastasio, P. A., Bachman, B. A., \& Rust, M. C. (1993). The common ingroup identity model: Recategorization and the reduction of intergroup bias. In W. Stroebe \& M. Hewstone (Eds.), European review of social psychology (Vol. 4, pp. 1-26). Chichester, UK: Wiley.

Gonzalez, R., \& Brown, R. (2006). Dual identities in intergroup contact: Group status and size moderate the generalization of positive attitude change. Journal of Experimental Social Psychology, 42, 753767. doi:10.1016/j.jesp.2005.11.008

Hogg, M. A. (2000). Subjective uncertainty reduction through self-categorization: A motivational theory of social identity processes. European Review of Social Psychology, 11, 223-255. doi:10.1080/14792772043000040

Hornsey, M. J., \& Hogg, M. A. (2000). Assimilation and diversity: An integrative model of subgroup relations. Personality and Social Psychology Review, 4, 143-156. doi:10.1207/s15327957pspr0402_03

Hu, L., \& Bentler, P. M. (1999). Cutoff criteria for fit indexes in covariance structure analysis: Conventional criteria versus new alternatives. Structural Equation Modelling, 6, 1-55. doi:10.1080/ 10705519909540118 
Islam, M. R., \& Hewstone, M. (1993). Dimensions of contact as predictors of intergroup anxiety, perceived out-group variability, and out-group attitude: An integrative model. Personality and Social Psychology Bulletin, 19, 700-710. doi:10.1177/0146167293196005

Jetten, J., Spears, R., \& Manstead, A. S. R. (1997). Distinctiveness threat and prototypicality: Combined effects on intergroup discrimination and collective self-esteem. European Journal of Social Psychology, 27, 635-657. doi:10.1002/ (sici)1099-0992(199711/12)27:6<635::aidejsp835>3.0.co;2-\#

Jetten, J., Spears, R., \& Manstead, A. S. R. (2001). Similarity as a source of differentiation: The role of group identification. European Journal of Social Psychology, 31, 621-640. doi:10.1002/ejsp.72

Jetten, J., Spears, R., \& Postmes, T. (2004). Intergroup distinctiveness and differentiation: A meta-analytic integration. Journal of Personality and Social Psychology, 86, 862-879. doi:10.1037/00223514.86.6.862

Judah, T. (2008). Kosovo: What everyone needs to know. New York, NY: Oxford University Press.

Lavrakas, P. J. (2008). Encyclopedia of survey research methods. Thousand Oaks, CA: SAGE.

Leach, C. W., van Zomeren, M., Zebel, S., Vliek, M. L. W., Pennekamp, S. F., Doosje, B., . . Spears, R. (2008). Group-level self-definition and self-investment: A hierarchical (multicomponent) model of in-group identification. Journal of Personality and Social Psychology, 95, 144-165. doi:10.1037/00223514.95.1.144

Maloku, E., Derks, B., van Laar, C., \& Ellemers, N. (2016). Building national identity in newborn Kosovo: Challenges of integrating national identity with ethnic identity among Kosovar Albanians and Kosovar Serbs. In S. McKeown, R. Haji \& N. Ferguson (Eds.), Understanding peace and conflict through social identity theory (pp. 245-260). New York, NY: Springer.

Miller, D. A., Smith, E. R., \& Mackie, D. M. (2004). Effects of intergroup contact and political predispositions on prejudice: Role of intergroup emotions. Group Processes \& Intergroup Relations, 7, 221-237. doi:10.1177/1368430204046109

Miller, K. P., Brewer, M. B., \& Arbuckle, N. L. (2009). Social identity complexity: Its correlates and antecedents. Group Processes \& Intergroup Relations, 12, 79-94. doi:10.1177/1368430208098778

Mullen, B., Brown, R., \& Smith, C. (1992). Ingroup bias as a function of salience, relevance, and status: An integration. European Journal of Social Psychology, 22, 103-122. doi:10.1002/ejsp.2420220202

Mummendey, A., \& Wenzel, M. (1999). Social discrimination and tolerance in intergroup relations: Reactions to intergroup difference. Personality and Social Psychology Review, 3, 158-174. doi:10.1207/ s15327957pspr0302_4

Muthén, L. K., \& Muthén, B. O. (1998-2015). Mplus user's guide (7th ed.). Los Angeles, CA: Muthén \& Muthén.

Pettigrew, T. F. (1998). Applying social psychology to international social issues. Journal of Social Issues, 54, 663-675. doi:10.1111/0022-4537.891998089

Pettigrew, T. F., \& Tropp, L. R. (2006). A meta-analytic test of intergroup contact theory. Journal of Personality and Social Psychology, 90, 751-783. doi:10.1037/0022-3514.90.5.751

Riek, B. M., Mania, E. W., \& Gaertner, S. L. (2006). Intergroup threat and outgroup attitudes: A meta-analytic review. Personality and Social Psychology Review, 10, 336-353. doi:10.1207/ s15327957pspr1004_4

Riek, B. M., Mania, E. W., Gaertner, S. L., McDonald, S. A., \& Lamoreaux, M. J. (2010). Does a common ingroup identity reduce intergroup threat? Group Processes \& Intergroup Relations, 13, 403-423. doi:10.1177/1368430209346701

Roccas, S., \& Brewer, M. B. (2002). Social identity complexity. Personality and Social Psychology Review, 6, 88-106. doi:10.1207/S15327957PSPR0602

Ron, Y., Solomon, J., Halperin, E., \& Saguy, T. (2016). Readiness to engage in intergroup contact: A multilevel approach. Peace and Conflict: Journal of Peace Psychology, 23, 210-218. doi:10.1037/pac0000204

Schmid, K., Hewstone, M., \& Al Ramiah, A. (2013). Neighborhood diversity and social identity complexity: Implications for intergroup relations. Social Psychological and Personality Science, 4, 135-142. doi:10.1177/1948550612446972

Schmid, K., Hewstone, M., \& Tausch, N. (2014). Secondary transfer effects of intergroup contact via social identity complexity. British Journal of Social Psychology, 53, 443-462. doi:10.1111/bjso.12045

Schmid, K., Hewstone, M., Tausch, N., Cairns, E., \& Hughes, J. (2009). Antecedents and consequences of social identity complexity: Intergroup contact, distinctiveness threat, and outgroup attitudes. Personality and Social Psychology Bulletin, 35, 1085-1098. doi:10.1177/0146167209337037

Sherman, D. K., Kinias, Z., Major, B., Kim, H. S., \& Prenovost, M. (2007). The group as a resource: 
Reducing biased attributions for group success and failure via group affirmation. Personality and Social Psychology Bulletin, 33, 1100-1112. doi:10.1177/0146167207303027

Sidanius, J., Feshbach, S., Levin, S., \& Pratto, F. (1997). The interface between ethnic and national attachment: Ethnic pluralism or ethnic dominance? Public Opinion Quarterly, 61, 102-133. doi:10.1086/297789

Sinclair, S., Sidanius, J., \& Levin, S. (1998). The interface between ethnic and social system attachment: The differential effects of hierarchy-enhancing and hierarchy-attenuating environments. Journal of Social Issues, 54, 741-757. doi:10.1111/00224537.931998093

Stangor, C., Sullivan, L. A., \& Ford, T. E. (1991). Affective and cognitive determinants of prejudice. Social Cognition, 9, 359-380. doi:10.1521/ soco.1991.9.4.359

Tajfel, H., \& Turner, J. (1979). An integrative theory of intergroup conflict. In W. G. Austin \& S. Worchel (Eds.), The social psychology of intergroup relations (pp. 33-47). Monterey, CA: Brooks/Cole.

Tajfel, H., \& Turner, J. C. (1986). The social identity theory of intergroup behavior. In S. Worchel \& W. G. Austin (Eds.), Psychology of intergroup relations (Vol. 2, pp. 7-24). Chicago, IL: Nelson-Hall.

Tausch, N., Hewstone, M., Kenworthy, J., Cairns, E., \& Christ, O. (2007). Cross community contact, perceived status differences and intergroup attitudes in Northern Ireland: The mediating roles of individual-level vs. group-level threats and the moderating role of social identification. Political Psychology, 28, 53-68. doi:10.1111/j.1467-9221.2007.00551.x

Terry, D. J., Carey, C. J., \& Callan, V. J. (2001). Employee adjustment to an organizational merger: An intergroup perspective. Personality and Social Psychology Bulletin, 27, 267-280. doi:10.1177/0146167201273001

Turner, J. C. (1985). Social categorization and the selfconcept: A social cognitive theory of intergroup behavior. In E. J. Lawler (Ed.), Advances in group processes (Vol. 2, pp. 77-122). Greenwich, CT: JAI.

Turner, J. C. (1999). Some current themes in research on social identity and self-categorization theories. In N. Ellemers, R. Spears, \& B. Doosje (Eds.), Social identity: Context, commitment, content (pp. 634). Oxford, UK: Blackwell.

Turner, J. C., Hogg, M. A., Oakes, P. J., Reicher, S. D., \& Wetherell, M. S. (1987). Rediscovering the social group: A self-categorization theory. Oxford, UK: Basil Blackwell.
Twenge, J. M., \& Crocker, J. (2002). Race and selfesteem: Meta-analyses comparing Whites, Blacks, Hispanics, Asians, and American Indians and comment on Gray-Little and Hafdahl (2000). Psychological Bulletin, 128, 371-408. doi:10.1037/00332909.128.3.371

Ufkes, E. G., Otten, S., van Der Zee, K. I., Giebels, E., \& Dovidio, J. F. (2012). Urban district identity as a common ingroup identity: The different role of ingroup prototypicality for minority and majority groups. European Journal of Social Psychology, 42, 706-716. doi:10.1002/ejsp.1888

United Nations Development Programme (UNDP). (2012). Public pulse report 3. Retrieved from http://www.ks.undp.org/content/kosovo/en /home/library/democratic_governance/public -pulse-3.html

Van Leeuwen, E., van Knippenberg, D., \& Ellemers, N. (2003). Continuing and changing group identities: The effects of merging on social identification and ingroup bias. Personality and Social Psychology Bulletin, 29, 679-690. doi:10.1177/0146167203029006001

Verkuyten, M., \& Martinovic, B. (2012). Immigrants' national identification: Meanings, determinants, and consequences. Social Issues and Policy Review, 6, 82-112. doi:10.1111/j.1751-2409.2011.01036.x Verkuyten, M., \& Yildiz, A. A. (2007). National (dis)identification and ethnic and religious identity: A study among Turkish-Dutch Muslims. Personality and Social Psychology Bulletin, 33, 1448-1462. doi:10.1177/0146167207304276

Villicana, A. J., Rivera, L. M., \& Garcia, D. M. (2017). When one's group is beneficial: The effect of group-affirmation and subjective group identification on prejudice. Group Processes \& Intergroup Relations. Advance online publication. doi:10.1177/1368430217690907

Waldzus, S., \& Mummendey, A. (2004). Inclusion in a superordinate category, in-group prototypicality and attitudes towards out-groups. Journal of Experimental Social Psychology, 40, 466-477. doi:10.1016/j. jesp.2004.05.006

Wohl, M. J., \& Branscombe, N. R. (2005). Forgiveness and collective guilt assignment to historical perpetrator groups depend on level of social category inclusiveness. Journal of Personality and Social Psychology, 88, 288-303. doi:10.1037/0022-3514.88.2.288

Xin, S., Xin, Z., \& Lin, C. (2016). Effects of trustors' social identity complexity on interpersonal and intergroup trust. European Journal of Social Psychology, 46, 428-440. doi:10.1002/ejsp.2156 